\title{
The anticancer effect of Ocimum tenuiflorum leaves
}

\author{
Lam, S.N., Neda, G.D. and *Rabeta, M.S. \\ Food Technology Division, School of Industrial Technology, Universiti Sains Malaysia, 11800 Minden, \\ Penang, Malaysia
}

\author{
Article history: \\ Received: 9 October 2017 \\ Received in revised form: 27 \\ October 2017 \\ Accepted: 30 October 2017 \\ Available Online: 2 \\ November 2017 \\ Keywords: \\ Breast cancer cell line, \\ MTT assay, \\ Ocimum tenuiflorum
}

DOI:

https://doi.org/10.26656/fr.2017.2(2).251

\begin{abstract}
Breast cancer is the leading cause of cancer deaths among females in Malaysia. Ocimum tenuiflorum L., (O. tenuiflorum) commonly known as ruku in Malaysia, is usually cultivated as a garden ornamental plant because of its small purplish and some yellowish flower. The specific objective of this research is to investigate the anticancer of $O$. tenuiflorum against human breast cancer cell lines (MCF-7 and MDA-MB-231) and human fibroblast cell line (HS-27). In addition, another objective is to determine the mineral and heavy metal determination of $O$. tenuiflorum. O. tenuiflorum exhibited anticancer activity against MCF-7 (a hormone-dependent breast cancer cell line). The viability of MCF-7 cells decreased significantly after treatment with various concentrations of methanolic plant extracts $(25$ and $100 \mu \mathrm{g} / \mathrm{mL})$, as shown via 3-(4,5dimethylthiazol-2-yl)2,5-diphenyltetrazolium bromide (MTT) assay. The crude extracts show the lower $\mathrm{IC}_{50}$ (less than $100 \mu \mathrm{g} / \mathrm{mL}$ ) value against the cancer cell lines and show no effect on HS-27. The high content of calcium in the leaves of $O$. tenuiflorum may play a role in decreasing the risk of certain cancer. The concentrations of heavy metals $(\mathrm{Pb}$ and As) detected in $O$. tenuiflorum are safe for consumption.
\end{abstract}

\section{Introduction}

In 2007, a report from the National Cancer Registry of Malaysia stated that 18219 new cases of cancer had been diagnosed, 8123 (44.6\%) of which were in males and $10096(55.4 \%)$ of which were in females (Zainal Ariffin and Nor Saleha, 2011). At that time, the ten leading cancers in the Malaysian population were breast, colorectal, lung, nasopharyngeal, and cervical cancers, lymphoma, leukemia, and ovarian, stomach and liver cancers (Zainal Ariffin and Nor Saleha, 2011).

In Malaysia, Ocimum tenuiflorum is commonly known as ruku, and it is usually cultivated as an ornamental garden plant because of its yellowish flower. Additionally, the young leaves of Ocimum tenuiflorum $L$. are used to make Nasi Ulam. Ocimum tenuiflorum $L$. is an herb with great medicinal and health potential (Kothari et al., 2004); the leaves have an essential oil that contains various compounds with medicinal value (Rai et al., 2004). Our previous study showed a possible use of $O$. tenuiflorum leaves in managing hyperglycemia and preventing the complications associated with it in
Type 2 Diabetes Mellitus (Leila et al., 2016). In vitro and in vivo studies have shown that zinc and magnesium inhibit the development of several types of cancer (Singh et al., 2012). The specific objective of this research was to investigate the anticancer activity of $O$. tenuiflorum against human breast cancer cell lines (MCF-7 and MDA -MB-231) and a human fibroblast cell line (HS-27). An additional objective was to determine the mineral and heavy metal content of $O$. tenuiflorum.

\section{Materials and methods}

\subsection{Plant materials}

The leaves of $O$. tenuiflorum were collected from Kuala Kurau in Peninsular Malaysia and were identified by Dr. Rahmad Zakaria from the School of Biological Sciences, Universiti Sains Malaysia. Leaves harvesting, and sample extraction were performed on the same day. Voucher specimen number 11400 was deposited in the herbarium laboratory of the School of Biological Sciences, Universiti Sains Malaysia. 


\subsection{Sample preparation}

The O. tenuiflorum leaves were separated from the stalks and the flowers. The leaves were washed thoroughly. Then, they were dried for 72 hours using a freeze dryer (ALPHA Freeze Dryer Model 1-2 LD plus, Vacuubrand, Germany). The dried leaves were then ground into a powder using a blender (Model BL 335, Kenwood, Selangor, Malaysia), stored in amber-colored glass bottles that were covered with aluminum foil, and kept airtight with Parafilm. The ground leaves were stored at $-20^{\circ} \mathrm{C}$ until further use.

\subsection{Water extraction}

Approximately $50 \mathrm{~g}$ of ground leaves were extracted for 4 hours in a bath of hot distilled water (EYELA Oil Bath model OSB-2000, Tokyo Rikakika Co., Ltd., Japan). The plant-to-water ratio was 1:20 and was based on the procedure of Huang et al. (2003). Whatman No. 1 filter paper was used to filter the resulting crude extract. The same volume of hot $\left(85^{\circ} \mathrm{C}\right)$ distilled water was added to repeat the extraction.

The crude extract was filtered using Whatman No. 1 filter paper. The filtrate was dried into a powder using a freeze dryer (ALPHA Freeze Dryer model 1-2 LD plus, Vacuubrand, Germany). The powdered extract was stored at $-20^{\circ} \mathrm{C}$ until further use.

\subsection{Methanol extraction}

Methanol extraction of the plant samples was conducted according to the method of Wicaksono et al. (2009). Approximately $100 \mathrm{~g}$ of ground O. tenuiflorum leaves were weighed using an analytical balance (METTLER TOLEDO Balance Model PL6001-S, Mettler-Toledo Inc., Columbus) and soaked in $300 \mathrm{~mL}$ of absolute methanol for one day. After soaking, the crude extract was filtered through Whatman No. 1 filter paper. This procedure was repeated twice. After repeated soaking and filtration, the residual methanol in the filtrate was evaporated under reduced pressure at $40{ }^{\circ} \mathrm{C}$ using a rotary evaporator (EYELA Rotary Evaporator model N-1000, Tokyo Rikakika Co., Ltd., Japan) connected to a water bath (EYELA Oil Bath model OSB -2000, Tokyo Rikakika Co., Ltd., Japan). The removal of residual methanol was followed by the evaporation of the methanolic extract at approximately $27^{\circ} \mathrm{C}$ (room temperature) for 2 days.

\subsection{MTT assay}

To produce a $1000 \mu \mathrm{g} / \mathrm{mL}$ of stock solution, about 5 $\mathrm{mg}$ of plant extract by the mean of water extraction and methanol extraction individually were mixed with $5 \mathrm{~mL}$ of PBS. The stock solution was diluted into concentration of $0.78 \mu \mathrm{g} / \mathrm{mL}, 1.56 \mu \mathrm{g} / \mathrm{mL}, 3.13 \mu \mathrm{g} / \mathrm{mL}$, $6.25 \mu \mathrm{g} / \mathrm{mL}, 12.5 \mu \mathrm{g} / \mathrm{mL}, 25 \mu \mathrm{g} / \mathrm{mL}, 50 \mu \mathrm{g} / \mathrm{mL}, 100 \mu \mathrm{g} /$ $\mathrm{mL}$. Each increasing concentration of the sample was added for treating the cells from the column $3(0 \mu \mathrm{g} / \mathrm{mL})$ to column $11(100 \mu \mathrm{g} / \mathrm{mL})$. After treating, the cells were incubated at $37^{\circ} \mathrm{C}$ with $5 \% \mathrm{CO}_{2}$ for 48 and $72 \mathrm{hrs}$. The test was triplicated. When incubation period achieved, each well was added with $12 \mu \mathrm{L}$ of MTT labelling reagent. The cells were incubated again at $37{ }^{\circ} \mathrm{C}$ with $5 \%$ $\mathrm{CO}_{2}$ for $4 \mathrm{hrs}$. Next, $100 \mu \mathrm{L}$ of acidified isopropanol and $100 \mu \mathrm{L}$ of distilled water were added into every well. Using ELISA reader (Thermo Scientific Spectrophotometer Model 1500-900, Fisher Scientific, Malaysia) at $550 \mathrm{~nm}$, the cell viability was detected.

\subsection{Measurement of the inhibition of cell proliferation}

After a 48-72 hours incubation period, approximately $24 \mu 1$ of 3-(4,5-dimethylthiazol-2-yl)2,5diphenyltetrazolium bromide (MTT) solution (Sigma Chemical Company, St. Louis, MO, USA) was added to each well of a 96-well plate, and the assay results were obtained based on the method described by Mossman (1983). The plate was tapped and gently shaken to mix the solution into the media. Then, the cells were incubated at $37^{\circ} \mathrm{C}$ in a humidified $\mathrm{CO}_{2}$ incubator for 4 hours. The media was removed, and $100 \mu 1$ of acidified isopropanol was added to each well. After 5 minutes, $100 \mu$ of autoclaved deionized water was added to each well and thoroughly mixed to permit color development. The absorbance at $570 \mathrm{~nm}$ was read using a spectrophotometric plate reader (Multiskan Spectrum; Thermo Electron Co., Waltham, MA, USA), and the proportion of surviving cells was calculated as:

$$
\text { Viability }(\%)=\frac{\text { OD of drug-tested sample-OD of blank }}{\text { OD of control-OD of blank }} \times 100
$$

Dose-response curves were constructed using probit analysis to obtain the $\mathrm{LC}_{50}$ and $\mathrm{LC}_{80}$ values. All experimental data were derived from at least three independent experiments.

A fibroblast cell line was used to analyze the extract's ability to kill normal cells. MCF-10A or HMEpC cells could have been used, but the former requires treatment with other factors that might affect the 'normal' character of the cells, whereas the latter are primary cells whose characteristics differ, making them unsuitable for the purposes of this study.

\subsection{Sample digestion}

Borgese et al. (2009) have reported a method for 
sample digestion that uses a microwave digester. First, $10 \mathrm{~mL}$ of nitric acid $\left(\mathrm{HNO}_{3}\right)$ was diluted to $50 \mathrm{~mL}$ with deionized water. The diluted $\mathrm{HNO}_{3}$ was used to rinse the apparatus and the centrifuge tubes to avoid contamination.

For both raw and powdered plant samples, between $500 \mathrm{mg}$ and $800 \mathrm{mg}$ was added to a digestion vessel using a clean spatula. The vessel was acidified with $7 \mathrm{~mL} \mathrm{HNO}_{3}$ and $1 \mathrm{~mL} \mathrm{HCl}$ in a fume hood. A digestion vessel containing $7 \mathrm{~mL} \mathrm{HNO}_{3}$ and $1 \mathrm{~mL} \mathrm{HCl}$ was used as a blank. The digestion vessel was placed into a rotor, and the rotor was then placed into the microwave digester (Multiwave 3000, Anton Paar, Austria). The process required $15 \mathrm{~min}$ to completely liquefy the sample. Once the digestion had finished, each vessel was carefully opened in the fume hood. The liquefied sample was filtered using ashless filter paper.

\subsection{Standard preparation for mineral and heavy metal analysis}

To determine the concentration of 21 standard elements [antimony ( $\mathrm{Sb})$, arsenic (As), beryllium $(\mathrm{Be})$, cadmium $(\mathrm{Cd})$, calcium $(\mathrm{Ca})$, chromium $(\mathrm{Cr})$, cobalt $(\mathrm{Co})$, copper $(\mathrm{Cu})$, iron $(\mathrm{Fe})$, lead $(\mathrm{Pb})$, lithium $(\mathrm{Li})$, magnesium $(\mathrm{Mg})$, manganese $(\mathrm{Mn})$, molybdenum (Mo), nickel $(\mathrm{Ni})$, selenium $(\mathrm{Se})$, strontium $(\mathrm{Sr})$, thallium $(\mathrm{Tl})$, titanium (Ti), vanadium (V) and zinc ( $\mathrm{Zn})$ ], standards of 1-, 2-, and 3-ppm solutions were prepared for each element from 10-ppm stock solutions. To analyze additional elements, 1-, 2-, and 3-ppm potassium standards were needed. A $0.1 \mathrm{~mL}$ volume of a $10-\mathrm{ppm}$ potassium standard was added to $1 \mathrm{~mL}$ of the standards of each of the 21 elements. Distilled water was added to the mixture to a final volume of $50 \mathrm{~mL}$. Micropipettes were used to obtain accurate results during standard preparation. Standard solutions of $0,1,3$ and 5 ppm were prepared for the analysis.

\subsection{Sample preparation for mineral and heavy metal analysis}

Firstly, eight centrifuge tubes were rinsed with nitric acid to prevent contamination. After the tubes dried, the raw plant sample solution obtained from the microwave digester was added to the tubes. One centrifuge tube was used as a blank. The mineral content $(\mathrm{Ca}, \mathrm{Pb}, \mathrm{Na}, \mathrm{K}, \mathrm{Mg}$, $\mathrm{Zn}, \mathrm{Co}, \mathrm{Fe}$ and $\mathrm{Cu}$ ) of the samples were analyzed via ICP-OES (Perkin Elmer, Optima 7000 DV). Five sample dilutions $(1: 10,1: 50,1: 100,1: 500$ and 1:1000) and a blank were prepared for the analysis. The wavelength of each element was then set. The concentrations of the elements were calculated based on their obtained intensity readings.

\subsection{Statistical analysis}

The cell viability results were calculated as means \pm standard deviations. To identify significant differences among multiple comparisons, one-way ANOVA analysis followed by Duncan's test with $\mathrm{p}<0.05$ was performed using SPSS version 20.0. The results of the mineral and heavy metal analysis were calculated as the means \pm standard deviations and were compared using t-tests.

\section{Results and Discussion}

\subsection{Cell viability}

The percentage of viable cells in the human cancer cell lines (MCF-7 and MDA-MB-231) and the noncancerous cell line (HS-27) after treatment with aqueous O. tenuiflorum extracts for 48 and 72 hours are shown in Figures 1 and 2, respectively, and the results of similar experiments using methanol extracts are shown in Figures 3 and 4 . In both cases, the extract concentrations were between $0 \mu \mathrm{g} / \mathrm{mL}$ and $100 \mu \mathrm{g} / \mathrm{mL}$. The active compounds should be resistant to heat treatment, as has been cited in empirical tests showing that heat-treated extracts are effective in traditional treatments. In addition, the hot water extraction method was chosen to reduce the number of compounds in the active fraction.

Figure 1 shows the effects of a 48-h treatment with the aqueous extract. Treatment with $6.25 \mu \mathrm{g} / \mathrm{mL}$ of extract $127.6 \%$ reduced the viability of MCF- 7 cells, and treatment with 3.13 and $12.5 \mu \mathrm{g} / \mathrm{mL}$ significantly reduced their viability to an even greater extent (100.7\% and $105.1 \%$, respectively) $(p<0.05)$. In MD-MB-231 cells, treatment with 0.78 and $6.25 \mu \mathrm{g} / \mathrm{mL}$ extract increased viability ( $121.7 \%$ and $126.4 \%$, respectively).

Figure 2 shows that the viability of MCF-7 cells for 72-h increased after treatment with 3.13 and $100 \mu \mathrm{g} / \mathrm{mL}$ extract (113.9\% and $99.2 \%$, respectively). The viability of MD-MB-231 cells increased significantly $(p<0.05)$ with $3.13 \mu \mathrm{g} / \mathrm{mL}$ extract $(113.9 \%)$. Therefore, the plant extract was more effective at decreasing MCF-7 cell viability at concentrations of between $6.25 \mu \mathrm{g} / \mathrm{mL}$ and $50 \mu \mathrm{g} / \mathrm{mL}$.

Figure 3 shows the effect of 48 -h treatments with methanolic plant extracts. After treatment with 25 and $100 \mu \mathrm{g} / \mathrm{mL}$ extract, the viability of MCF-7 cells decreased significantly $(p<0.05)(94.1 \%$ and $95.3 \%$, respectively. Thus, the plant extract inhibited the growth of these hormone-dependent breast cancer cells. The viability of MDA-MB-231 cells decreased significantly 


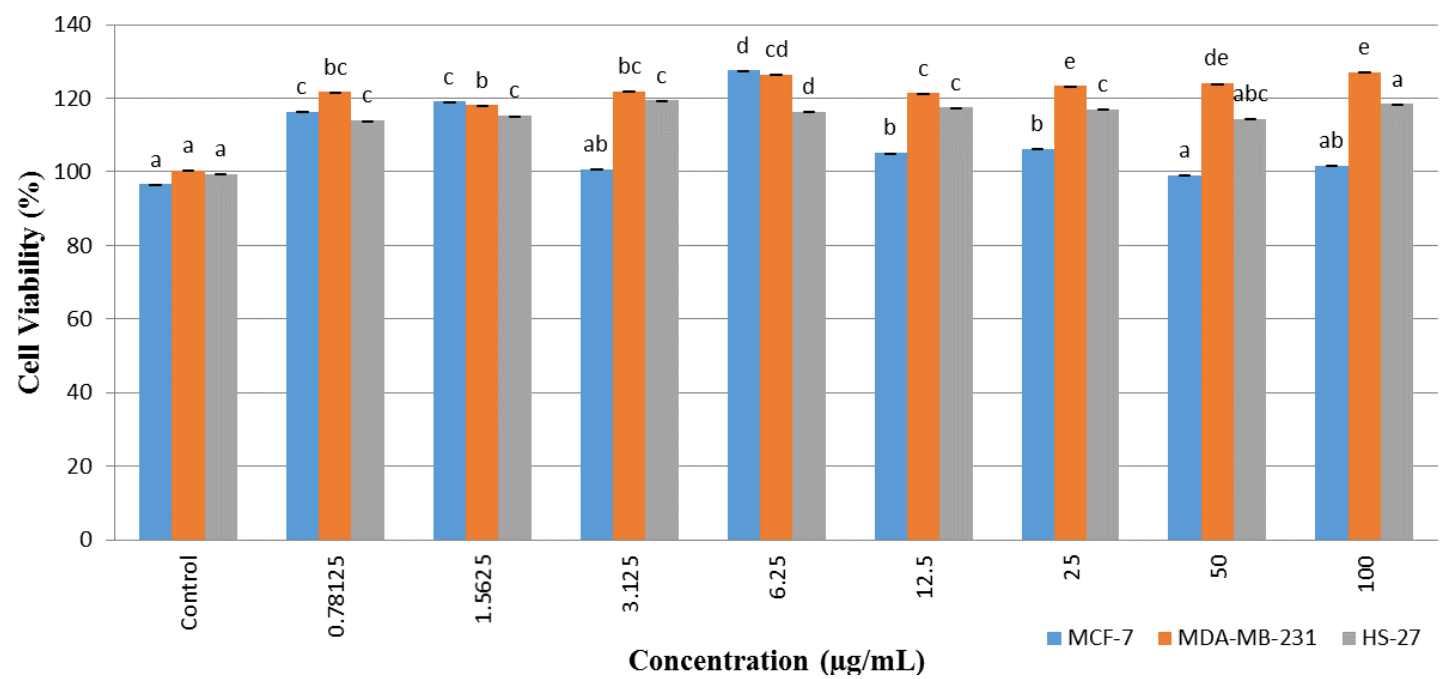

Figure 1. Cell Viability of $O$. tenuiflorum with water extraction at different concentration for 48 hours. Values are presented as mean \pm standard deviation of triplicate measurements.

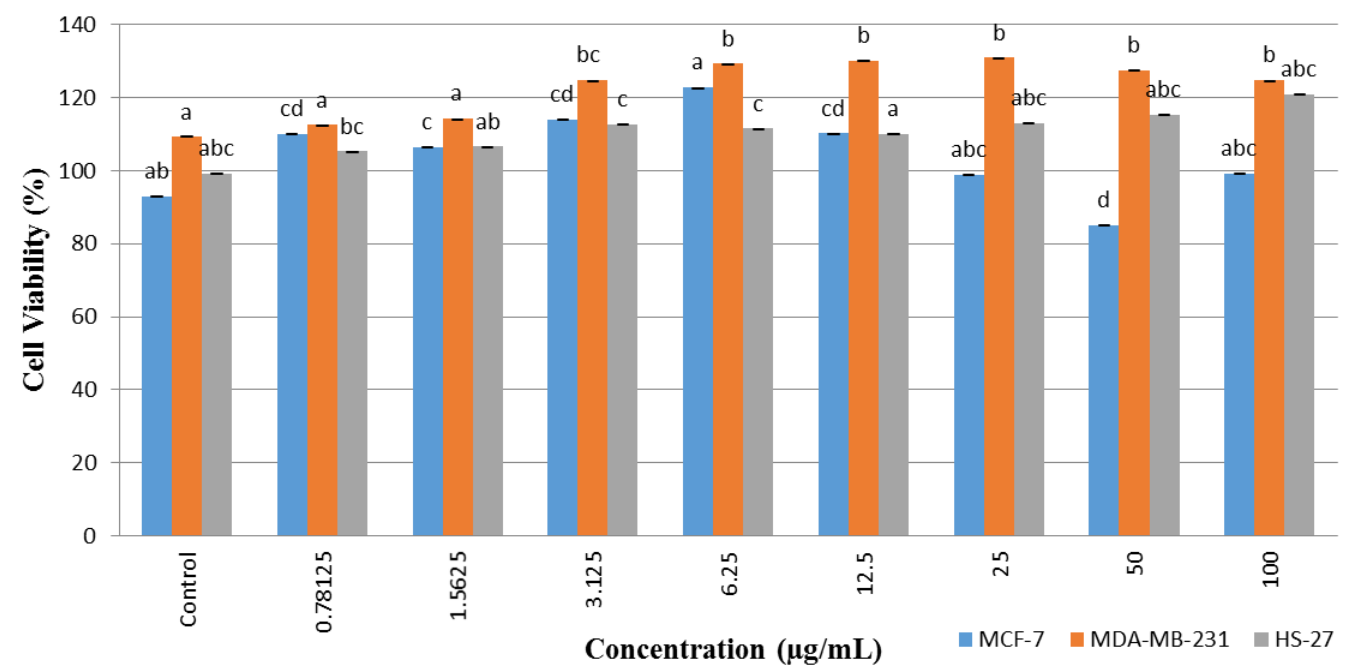

Figure 2. Cell Viability of $O$. tenuiflorum with water extraction at different concentration for 72 hours. Values are presented as mean \pm standard deviation of triplicate measurements.

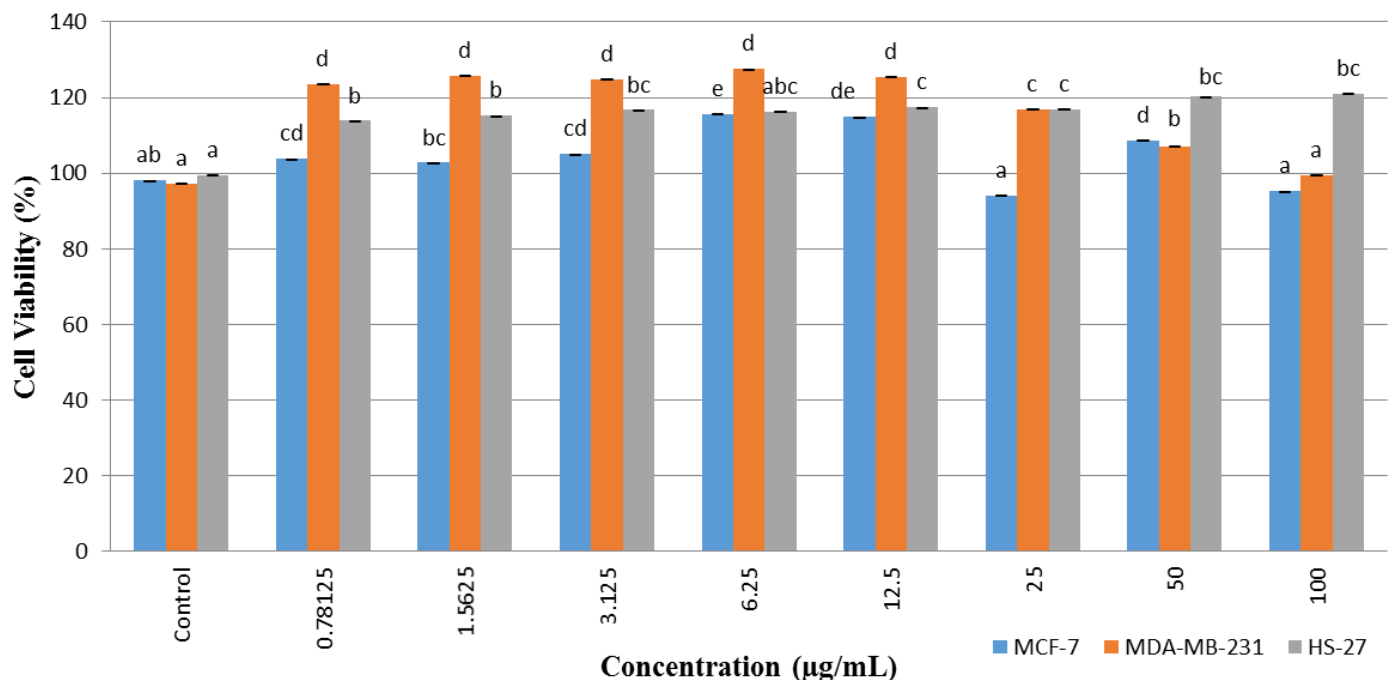

Figure 3. Cell Viability of $O$. tenuiflorum with methanol extraction at different concentration for 48 hours. Values are presented as mean \pm standard deviation of triplicate measurements. 


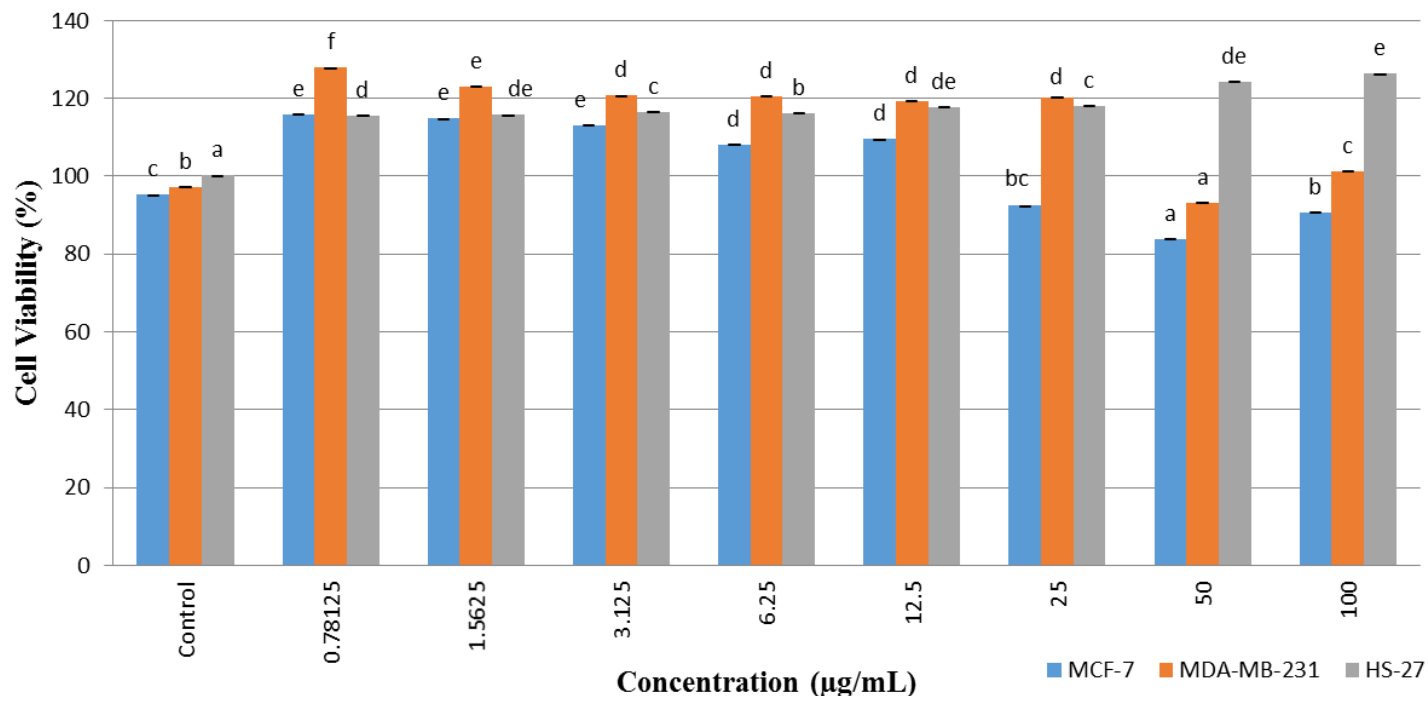

Figure 4. Cell Viability of $O$. tenuiflorum with methanol extraction at different concentration for 72 hours. Values are presented as mean \pm standard deviation of triplicate measurements.

with treatments of between $25 \mu \mathrm{g} / \mathrm{mL}$ and $100 \mu \mathrm{g} / \mathrm{mL}$ $(p<0.05)(116.9 \%$ and $99.6 \%)$.

Figure 4 shows that the viability of MCF-7 cells decreased significantly $(p<0.05)$ after $72 \mathrm{~h}$ of treatment with 25 or $50 \mu \mathrm{g} / \mathrm{mL}$ methanolic plant extracts $(92.4 \%$ and $83.8 \%$, respectively). The difference in viability after treatment with 1.56 or $3.13 \mu \mathrm{g} / \mathrm{mL}$ extract was not significant $(p>0.05) \quad(114.8 \%$ and $113.2 \%$, respectively). Thus, cancer cell growth was not inhibited. The HS-27 viability did not decrease significantly across the different concentrations $(p>0.05)$. Therefore, the $50 \mu \mathrm{g} / \mathrm{mL}$ plant extract was the most effective against MCF-7 cells.

Samresh et al. (2003) have reported on the anticancer activity of $O$. tenuiflorum leaves, which inhibit chromosomal abnormalities in the bone marrow and suppress tumors in the forestomach of mice. Natural plant polyphenolic substances have been reported to inhibit cancer (Cognault et al., 2000). One of the most important polyphenolic classes is that of the flavonoids (Rahmatullah et al., 2010), which have been found in O. tenuiflorum (Samresh et al., 2003). According to Umadevi (2001), orientin and vicenin, which are radioprotective flavonoids found in $O$. tenuiflorum, exhibit activity against hydroxyl radicals. Free radicals that damage tissues and cause diseases are produced regularly (Halliwell and Gutteridge, 1998).

The increased use of $O$. tenuiflorum in horticulture will be advantageous for cancer chemoprevention in the future. Moreover, O. tenuiflorum can be incorporated into food (Trevisan et al., 2006).

Studies on the volatile constituents of oil isolated from $O$. tenuiflorum via hydrodistillation have been described by the Association of Official Analytical Chemists (Tharmolwan et al., 2010). Eugenol is a phenolic compound found in the volatile oils of Ocimum species (Prakash and Gupta 2005). A similar report by Kothari et al. (2004) showed that the oil isolated from $O$. tenuiflorum contains eugenol. $O$. tenuiflorum oil suppresses the genotoxicity of the MCF-7 cell line to regulate enzymes responsible for detoxification such as quinine oxidoreductase (Han et al., 2007).

MCF-7, a hormone-dependent breast cancer cell line, is classified as estrogen receptor (ER)-positive, whereas MDA-MB-231, a non-hormone-dependent breast cancer cell line, is classified as ER-negative (Magdalena et al., 2013). The treatments for these two types of breast cancer differ. ER-positive cancer requires radiation, chemotherapy, surgery and estrogen analogs. Estrogen analogs are not effective against ER-negative cancer because of its estrogen-independent property. Estrogen activity may be affected by the presence of polyphenols that suppress hormone-producing enzymes (Hakimuddin et al., 2008).

Hakimuddin et al. (2008) reported that the polyphenols in 0 . tenuiflorum may inhibit MCF-7 cells. The estrogen-dependent proliferation of MCF-7 cells can be influenced by polyphenols (Hakimuddin et al., 2008). This inhibitory effect has not been shown in MDA-MB231 or HS-27 cells. The methanolic plant extracts had greater effects than the aqueous plant extracts, which may be due to the greater solubility of plant compounds in organic solvents. This result correlated with the finding of Gulluce et al. (2007), who stated that methanol extracts are particularly strong free radical scavengers because of their total phenol and flavonoid content (Rabeta and Lai, 2013). 


\subsection{Mineral and heavy metal analysis}

Minerals might affect active compound activity and cell viability. Hence, because some minerals might be lost during sample preparation, it would be appropriate to determine the mineral content of the different extracts. The mineral and heavy metal contents of $O$. tenuiflorum are given in Tables 1 and 2. O. tenuiflorum had more $\mathrm{K}$ and $\mathrm{Na}(2534.38 \pm 12.74$ and $319.77 \pm 6.45 \mathrm{mg} / \mathrm{kg}$, respectively) than $\mathrm{did} O$. tenuiflorum powder $(2458.37 \pm 25.38$ and $240.05 \pm 4.02 \mathrm{mg} / \mathrm{kg}$, respectively). The $\mathrm{K}$ and $\mathrm{Na}$ content of the $O$. tenuiflorum powder was significantly less than that of $O$. tenuiflorum $(p<0.05)$. In a study by Mehmet et al. (2008), the $\mathrm{K}$ content of $O$. basillum (11 $160.4 \pm 1145.31 \mathrm{mg} / \mathrm{kg})$ was shown to be greater than that of $O$. tenuiflorum, whereas the Na content of $O$. basillum $(65.24 \pm 33.14 \mathrm{ppm})$ was less than that of $O$. tenuiflorum. Results from Pachkore and Dhale (2012) showed that the $\mathrm{K}$ content of $O$. basillum, $O$. gratissimum and $O$. sanctum was $3669.4 \pm 4.53$, $1498.5 \pm 8.34$ and $3969.4 \pm 4.98 \mathrm{mg} / \mathrm{kg}$, respectively. The results obtained in the present study are in line with those of Pachkore and Dhale (2012). High potassium intake in the diet can reduce the risk of hypertension and possibly stroke (Devesh et al., 2012).

Table 1. Concentration of mineral contents in Ocimum tenuiflorum and Ocimum tenuiflorum powder

\begin{tabular}{ccc}
\hline \multirow{2}{*}{ Element } & \multicolumn{2}{c}{ Concentration (mg/kg sample) } \\
\cline { 2 - 3 } & Ocimum tenuiflorum & $\begin{array}{c}\text { Ocimum tenuiflorum } \\
\text { powder }\end{array}$ \\
\hline $\mathrm{K}$ & $534.38 \pm 12.74^{\mathrm{a}}$ & $458.37 \pm 25.38^{\mathrm{b}}$ \\
$\mathrm{Na}$ & $319.77 \pm 6.45^{\mathrm{a}}$ & $240.05 \pm 4.02^{\mathrm{b}}$ \\
$\mathrm{Ca}$ & $200 \pm 4.21^{\mathrm{a}}$ & $171.68 \pm 3.90^{\mathrm{b}}$ \\
$\mathrm{Mg}$ & $34.29 \pm 3.02^{\mathrm{a}}$ & $41.07 \pm 2.41^{\mathrm{b}}$ \\
$\mathrm{Fe}$ & $2.57 \pm 0.022^{\mathrm{a}}$ & $3.11 \pm 0.27^{\mathrm{b}}$ \\
$\mathrm{Zn}$ & $1.49 \pm 0.025^{\mathrm{a}}$ & $2.75 \pm 0.35^{\mathrm{b}}$ \\
$\mathrm{Co}$ & $0.25 \pm 0.049^{\mathrm{a}}$ & $0.24 \pm 0.01^{\mathrm{a}}$ \\
$\mathrm{Cu}$ & $0.60 \pm 0.01^{\mathrm{b}}$ & $0.67 \pm 0.024^{\mathrm{b}}$ \\
\hline
\end{tabular}

Values are mean \pm standard deviation $(n=3)$. Values with different letters within rows are significantly different $(\mathrm{p}<0.05)$.

Table 2. Concentration of heavy metals in Ocimum tenuiflorum and Ocimum tenuiflorum powder

\begin{tabular}{ccc}
\hline \multirow{2}{*}{ Element } & \multicolumn{2}{c}{ Concentration (mg/kg sample) } \\
\cline { 2 - 3 } & Ocimum tenuiflorum & $\begin{array}{c}\text { Ocimum tenuiflorum } \\
\text { powder }\end{array}$ \\
\hline $\mathrm{Pb}$ & $1.88 \pm 0.47^{\mathrm{a}}$ & $1.15 \pm 0.052^{\mathrm{a}}$ \\
$\mathrm{As}$ & $0.013 \pm 0.001^{\mathrm{a}}$ & $0.014 \pm 0.001^{\mathrm{a}}$ \\
\hline
\end{tabular}

Values are mean \pm standard deviation $(n=3)$. Values with different letters within rows are significantly different $(\mathrm{p}<0.05)$.
Table 1 shows that the $\mathrm{Ca}$ content of $O$. tenuiflorum $(200 \pm 4.21 \mathrm{mg} / \mathrm{kg})$ is higher than that of O. tenuiflorum powder $(171.68 \pm 3.90 \mathrm{mg} / \mathrm{kg})$. Calcium is important for conducting nerve impulses and for building strong bones (Devesh et al., 2012). O. basillum has a greater $\mathrm{Ca}$ content $(574.7 \pm 57 \mathrm{mg} / \mathrm{kg})$ than does O. tenuiflorum (Mehmet et al., 2008). Results from Ozcan (2004) show the $\mathrm{Ca}$ content of $O$. basillum to be even greater (12363 mg/kg).

Some studies have suggested that high levels of calcium in the diet can decrease the risk of cancer (Wargovich et al., 1991). A significant interaction between calcium and tumor formation has been discovered (Pence et al., 1996); a study by Pence et al. (1996) found that calcium could inhibit carcinogeninduced colon tumorigenesis in rats. Calcium can be obtained from foods such as soybeans, tofu, sweet potatoes and low oxalate vegetables (e.g., kale and broccoli) (Connie et al., 1999).

O. tenuiflorum had significantly less $\mathrm{Mg}$ than it did in its powder form $(34.29 \pm 3.02 \mathrm{mg} / \mathrm{kg}$ and $41.07 \pm 2.41 \mathrm{mg} / \mathrm{kg}$, respectively). These levels are low relative to those measured by Mehmet et al. (2008) in Ocimum species $(513.2 \pm 280.93 \mathrm{mg} / \mathrm{kg})$. Magnesium is responsible for calcium metabolism in bones (Ishida et al., 2000). Foods such as dark bread, cold cereal and bananas are sources of magnesium (Tucker et al., 1999).

In addition to the macroelements, the concentrations of microelements such as $\mathrm{Fe}, \mathrm{Pb}, \mathrm{Zn}, \mathrm{Co}$, and $\mathrm{Cu}$ were determined. The $\mathrm{Fe}(2.57 \pm 0.02 \mathrm{mg} / \mathrm{kg})$ and $\mathrm{Zn}$ $(1.49 \pm 0.025 \mathrm{mg} / \mathrm{kg})$ levels measured in O. tenuiflorum were significantly higher than the corresponding $\mathrm{Fe}$ and $\mathrm{Zn}$ levels in its powdered form. These results were not within the ranges of values reported by Ozcan (2004), who showed the $\mathrm{Fe}$ and $\mathrm{Zn}$ content of $O$. basillum to be 503 and $13.7 \mathrm{mg} / \mathrm{kg}$, respectively. Aluko et al. (2012) also reported high $\mathrm{Fe}$ and $\mathrm{Zn}$ content in $O$. canum (185 \pm $0.02 \mathrm{mg} / \mathrm{kg}$ and $130 \pm 0.01 \mathrm{mg} / \mathrm{kg}$, respectively). The WHO recommends a minimum Fe concentration of 15 $\mathrm{mg} / \mathrm{kg}$ in food (Anthony et al., 2013). The $\mathrm{Cu}$ content determined by Ozcan (2004) was between $0.6 \mathrm{mg} / \mathrm{kg}$ and $0.9 \mathrm{mg} / \mathrm{kg}$, which was comparable with the $\mathrm{Cu}$ content of $O$. tenuiflorum. Copper deficiency can cause hypertension, hyperglycemia and antibiotic sensitivity (Devesh et al., 2012).

The mineral content of plants can be influenced by differences in geography, growth conditions, species, genetics and analytical procedures (Ozcan, 2004). Geographic variations can include climatic variables such as temperature and the length of the growing season 
(Reich and Oleksyn, 2004). Growth conditions such as climate, soil, and plant functional type are other factors that influence the mineral and heavy metal contents of plants (Reich and Oleksyn, 2004; Kara, 2009). The increased $\mathrm{Cu}, \mathrm{Zn}$ and $\mathrm{Fe}$ content of $O$. tenuiflorum powder could be caused by the techniques and substances used during processing, such as are used in the cutting, grinding or blending of the plant. The $\mathrm{Zn}$ concentration in Lycopersicon esculentum increases by using iron pots during cooking (Anthony et al., 2013). Conversely, $\mathrm{K}$ and $\mathrm{Na}$ levels can be reduced by heating and washing. The passive diffusion of water-soluble $\mathrm{Na}$ and $\mathrm{K}$ in legume flour has been reported by Christine and Rosalind (2007).

From Table 2, the $\mathrm{Pb}$ content $(2.10 \mathrm{mg} / \mathrm{kg})$ displayed by was more than that of Ocimum tenuiflorum. The $\mathrm{Pb}$ content determined in Aluko et al. (2012) was $20 \pm 0.01 \mathrm{mg} / \mathrm{kg}$ that considered relatively higher than that of Ocimum tenuiflorum. Due to the accumulation potential of As, it was selected to be analyzed. The As content in both Ocimum tenuiflorum samples was lower than that of value collected by Mehmet et al. (2008) $(5.3 \pm 5.19 \mathrm{mg} / \mathrm{kg})$. The result of Mehmet et al. (2008) showed that the As intake exceed $0.015 \mathrm{mg} / \mathrm{kg}$ set by Food and Agricultural Organization World Health Organization Joint Expert Committee on Food Additives (Harriet et al., 2012). Besides, the Scientific Committee of the European Food Safety Authority (EFSA) stated that it is important to ensure the botanical ingredients used in food supplements are safe to consume and $O$. tenuiflorum that is possible to cause reproduction toxicity was evaluated. The result of the evaluation showed that there was no information regarding toxic compounds for that effect (Gerrit et al., 2010).

\section{Conclusion}

O. tenuiflorum exhibited anticancer activity against some cancerous cell lines, and especially against MCF-7, a hormone-dependent breast cancer cell line. The viability of MCF-7 cells decreased significantly $(\mathrm{p}<0.05)$ and the best concentration of $O$. tenuiflorum was $25 \mu \mathrm{g} / \mathrm{ml}$ of methanolic extracts after 48 and $72 \mathrm{~h}$ (94\% and $92.4 \%$, respectively). The concentrations of heavy metals ( $\mathrm{Pb}$ and $\mathrm{As}$ ) measured in $O$. tenuiflorum are low enough to be safe for consumption.

\section{Acknowledgements}

Universiti Sains Malaysia Short Term Grants (304/ PTEKIND/6310065) and (304/PTEKIND/6312124) contributed to the funding of this research.

\section{References}

Aluko, B.T., Oloyede, O.I. and Afolayan, A.J. (2012). Phytochemical and Nutrient Compositions of the Leaves of Ocimum canum Sims. African Journal of Biotechnology, 11(63), 12697-12701. https:// doi.org/10.5897/AJB11.3418

Anthony, B., Ojekale, C., Chukwu, G., Oladipupo, Lawal O. and Titilola, S.O. (2013). Some Nigerian Traditional Food Milling Techniques and Cookware Increase Concentrations of Some Heavy Metals in Lycopersicon Esculentum and Citrullus Lanatus. IOSR Journal of Pharmacy, 3(3), 6-13. https:// doi.org/10.9790/3013-03310613

Borgese, Z.A., Bontempi E., Colombi, P.B.R. and Ferretti, E. (2009). Total Reflection of X-ray Fluorescence (TXRF): A Mature Technique for Environmental Chemical Nanoscale Metrology. Measurement Science and Technology, 20, 1-7. https://doi.org/10.1088/0957-0233/20/8/084027

Christine, H. and Rosalind, G.N. (2007). Traditional Food-Processing and Preparation Practices to Enhance the Bioavailability of Micronutrients in Plant-Based Diets. Journal of Nutrition, 137(4) 1097 -1100 .

Cognault, M., Jourdan M.L. and Germain E. (2000). Effect of an $\alpha$-Linolenic Acid-Rich Diet on Rat Mammary Tumor Growth Depends on the Dietary Oxidative Status. Nutrition and Cancer, 36(1), 3341. https://doi.org/10.1207/S15327914NC3601_6

Connie M Weaver, William R Proulx and Robert Heaney. (1999). Choices for Achieving Adequate Dietary Calcium with a Vegetarian Diet. The American Journal of Clinical Nutrition, 70(3), 543548.

Devesh, T., Pandeyb, H.K., Saha, A.N., Meenab, H.S. and Manchanda, A. (2012). Pharmacognostical and Biochemical Investigation of Ocimum kilim and scharicum Plants Available in Western Himalayan Region. Asian Journal of Plant Science and Research, 2(4), 446-451.

Gerrit S., Bottex, B., Dusemund, B., Lugasi, A., Toth, J., Amberg-Muller, J., Galli, C.L., Silano, V. and Rietjens, I.M.C.M. (2010). Safety Assessment of Botanicals and Botanical Preparations Used as Ingredients in Food Supplements: Testing an European Food Safety Authority-tiered Approach. Molecular Nutrition and Food Research, 54(2), 175185. https://doi.org/10.1002/mnfr.200900240

Gulluce, M., Sahin, F., Sokmen, M., Ozer, H., Daferera, D., Sokmen, A., Polissiou, M., Adiguzel, A. and 
Ozkan, H. (2007). Antimicrobial and Antioxidant Properties of the Essential Oils and Methanol Extract from Mentha longifolia L. ssp. Longifolia. Food Chemistry, 103(4), 1449-1456. https:// doi.org/10.1016/j.foodchem.2006.10.061

Hakimuddin, F., Tiwari, K., Paliyah, G. and Meckling, K. (2008). Grape and Wine Polyphenols Downregulate the Expression of Signal Transduction Genes and Inhibit the Growth of Estrogen ReceptorNegative MDA-MB-231 Tumors in nu/nu Mouse Xenografts. Nutrition Research, 28, 702-713. https:// doi.org/10.1016/j.nutres.2008.06.009

Halliwell, B. and Gutteridge, J.M. (1998). Free Radicals in Biology and Medicine, p. 203-209. United Kingdom: Oxford

Han, E.H., Hwang, Y.P., Jeong, T.C., Lee, S.S., Shin, J.G. and Jeong H.G. (2007). Eugenol Inhibit 7,12dimethylbenz[a]anthracene-induced Genotoxicity in MCF-7 Cells: Bifunctional Effects on CYP1 and NAD (P) H:quinone oxidoreductase. FEBS Letters 581, 749-756. https://doi.org/10.1016/ j.febslet.2007.01.044

Harriet, O., Barbara, N., Keleabetswe, M.R. and AndraeMarobela, K. (2012). Determination of Potentially Toxic Heavy Metals in Traditionally Used Medicinal Plants for HIV/AIDS Opportunistic Infections in Ngamil and District in Northern Botswana. Analytica Chimica Acta, 730, 42-48. https://doi.org/10.1016/ j.aca.2011.11.067

Huang, S.T., Yang, R.C., Yang, L.J., Lee, P.N. and Pang, J.H.S. (2003). Phyllanthus Urinaria Triggers the Apoptosis and Bcl-2 Down-regulation in Lewis Lung Carcinoma Cells. Life Sciences, 72, 17051716. https://doi.org/10.1016/S0024-3205(03)00016$\mathrm{X}$

Ishida, H., Suzuno, H., Sugiyama, N., Innami, S. and Todokoro, T. (2000). National Evaluation of Chemical Component of Leaves Stalks and Stem of Sweet Potatoes, Ipomea Batatas Poir. Food Chemistry, 68, 359-367. https://doi.org/10.1016/ S0308-8146(99)00206-X

Kara, D. (2009). Evaluation of Trace Metal Concentrations in some Herbs and Herbal Teas by Principal Component Analysis. Food Chemistry, 114, 347-354. https://doi.org/10.1016/ j.foodchem.2008.09.054

Kothari S.K., Bhattacharya, A.K. and Ramesh S. (2004). Essential Oil Yield and Quality of Methyl Eugenol Rich Ocimum tenuiflorum L. f. (syn. O. sanctum L.) Grown in South India as Influenced by Method of Harvest. Journal of Chromatography A., 1054, 67-
72. https://doi.org/10.1016/j.chroma.2004.03.019

Leila, M., Rabeta, M.S., Vikneswaran, M. and Mohd Zaini, A. (2016). Hypoglycemic and antihyperglycemic study of Ocimum tenuiflorum L. leave extracts in Normal and Streptozotocin induced diabetic rats. Asian Pacific Journal of Tropical Biomedicine, 6(12), 1029-1036. https:// doi.org/10.1016/j.apjtb.2016.10.002

Magdalena, K., Rafał, G., Urszula, C., SzydłowskaPazera, K.., Piotr, P., Janusz, P., Arkadiusz, J. and Beata, O. (2013). Changes in plasma thiol levels induced by different phases of treatment in breast cancer; the role of commercial extract from black chokeberry. Molecular and Cellular Biochemistry, 372(1-2), 47-55. https:// doi.org/10.1007/s11010-012-1444-2

Mehmet, M.O., Ahmet, U., Tolga, U. and Derya, A. (2008). Mineral Content of Some Herbs and Herbal Teas by Infusion and Decoction. Food Chemistry, 106(3), 1120-1127. https://doi.org/10.1016/ j.foodchem.2007.07.042

Mossman, T. (1983). Rapid colorimetric assay for cellular growth and survival: application to proliferation and cytotoxicity assays. Journal of Immunological Methods, 65(1-2), 55-63. https:// doi.org/10.1016/0022-1759(83)90303-4

Ozcan, M. (2004). Mineral contents of some plants used as condiments in Turkey. Food Chemistry, 84, 437440. https://doi.org/10.1016/S0308-8146(03)00263-2

Pachkore, G.L. and Dhale, D.A. (2012). Phytochemicals, Vitamins and Minerals Content of Three Ocimum Species. International Jornal of Science Innovations and Discoveries, 2(1), 201-207.

Pence, B.C., Dunn, D.M., Zhao, C., Patel, V., Hunter, S. and Landers, M. (1996). Protective Effects of Calcium from Non-fat Dried Milk against Colon Carcinogenesis in Rats. Nutrition and Cancer, 25, 35 -45. https://doi.org/10.1080/01635589609514426

Prakash, P. and Gupta, N. (2005). Therapeutic Uses of Ocimum Sanctum Linn (Tulsi) with a Note on Eugenol and its Pharmacological Actions: A Short Review. Indian J Physiol Pharmacol, 49(2), 125131.

Rabeta, M.S and Lai, S.Y. (2013). Effects of drying, fermented and unfermented tea of Ocimum tenuiflorum Linn. on the antioxidant capacity. International Food Research Journal, 20(4), 16011608.

Rahmatullah, M., Rahman, M.A., Hossan, M.S., TaufiqUr-Rahman, M., Jahan, R. and Mollik, M.A.H. 
(2010). A Pharmacological and Phytochemical Evaluation of Medicinal Plants Used By the Harbang Clan of the Tripura Tribal Community of Mirsharai Area, Chittagong District, Bangladesh. Journal of Alternative and Complementary Medicine, 16(7), 769-785. https://doi.org/10.1089/ acm.2009.0497

Rai, V., Vajpayee, P., Singh, S.N. and Mehrotra, S. 2004. Effect of chromium accumulation on photosynthetic pigments, oxidative stress defense system, nitrate reduction, proline level and eugenol content of Ocimum tenuiflorum L. Plant Science, 167, 1159-1169. https://doi.org/10.1016/ j.plantsci.2004.06.016

Reich, P.B. and Oleksyn, J. (2004). Global Patterns of Plant Leaf $\mathrm{N}$ and $\mathrm{P}$ in relation to Temperature and Latitude. Proceedings of the National Academy of Sciences, 101, 11001-11006. https:// doi.org/10.1073/pnas.0403588101

Samresh, D., Srivastava, A., Singh, V. and Sharma, A. (2003). An Overview of Ocimum Chemistry and Pharmacological Profile. Hamdard Medicus, 46(4), 43.

Singh, M., Kumar, D., Singh, G., Sharma, D. and Swami, G. (2012). Natural Minerals and Cancer. Journal of Applied Pharmaceutical Science, 2(4), 158-165. https://doi.org/10.7324/JAPS.2012.2513

Tharmolwan, S., Watcharaporn, N. A., Thanapat, S., Suwan, T. and Somlak P. (2010). Antioxidant Activity and Lipid-Lowering Effect of Essential Oils Extracted from Ocimum sanctum L. Leaves in Rats Fed with a High Cholesterol Diet. Journal of Clinical Biochemistry and Nutrition, 46(1), 52-59.

Trevisan, M.T.S., Silva, M.G.V., Pfundstein, B., Speigelhalder, B. and Owen, R.W. (2006). Characterization of the Volatile Pattern and Antioxidant Capacity of Essential Oils from Different Species of the Genus Ocimum. Journal of Agricultural and Chemistry, 54(12), 4378-4382. https://doi.org/10.1021/jf060181+

Tucker, K.L., Hannan, M.T., Chen, H., Cupples, L.A., Wilson, P.W. and Kiel, D.P. (1999). Potassium, Magnesium, and Fruit and Vegetable Intakes are Associated with Greater Bone Mineral Density in Elderly Men and Women. The American Journal of Clinical Nutrition 69(4), 727-736.

Umadevi, P. (2001). Radioproctective, anticarcinogenic and antioxidant properties of the Indian Holy Basil, Ocimum Sanctum (Yulsi). India Journal of Experimental Biology, 309, 185-190.
Wargovich, M.J, Lynch, P.M. and Levin, B. (1991). Modulating Effects of Calcium in Animal Models of Colon Carcinogenesis and Short Term Studies in Subjects at Increased Risk of Colon Cancer. American Journal of Clinical Nutrition, 54, 20252055.

Wicaksono, B.D., Handoko, Y.A., Arung, E.T., Kusuma, I.W., Yulia, D., Pancaputra, A.N. and Sandra, F. (2009). Antiproliferative Effect of the Methanol Extract of Piper crocatum Ruiz and Pav Leaves on Human Breast (T47D) Cells In-vitro. Tropical Journal of Pharmaceutical Research, 8 (4), 345-352.

Zainal Ariffin, O. and Nor Saleha, I. (2011). National Cancer Registry Report 2007. Malaysia Cancer Statistics- Data and Figure. Kuala Lumpur: National Cancer Registry, Ministry of Health Malaysia. 